\title{
Katharina Reichert • Friedrich Buchholz \\ Changes in the macrozoobenthos of the intertidal zone at Helgoland (German Bight, North Sea): a survey of 1984 repeated in 2002
}

Received: 22 September 2005/ Revised: 1 January 2006/ Accepted: 23 January 2006/Published online: 3 March 2006

(c) Springer-Verlag and AWI 2006

\begin{abstract}
Changes in the presence and absence of invertebrates as well as in species conspicuousness were documented in a rocky intertidal community based on surveys in 1984 and 2002. In 2002 six vertically and/or morphologically different stations of an intertidal platform were sampled. Five of these six habitats had already been surveyed in 1984. Replicating precisely the method of the first assessment, presence/absence changes as well as changes in species conspicuousness of 83 invertebrate species were documented, indicating that this intertidal community changed considerably during the 18-year interval. Compared with the study in 1984, 27 species newly appeared, whereas 32 species disappeared. Furthermore, 16 species increased in conspicuousness, whereas eight invertebrates decreased. The total number of species in 2002 was 154 versus 158 in 1984. Although algal species were not recorded as thoroughly as invertebrates, a massive decline in cover of Halidrys siliquosa was noted. Conversely, two invasive algal species became established after 1984, Sargassum muticum (since 1988), a cosmopolitan fucoid alga that prefers shallow subtidal areas for colonization, and Mastocarpus stellatus (introduction in the 1980s) that particularly colonized areas in the mid intertidal. In 1984 the mid intertidal zone was dominated by the brown alga Fucus serratus, whereas in 2002 the blue mussel Mytilus edulis and the periwinkle Littorina littorea were the most conspicuous organisms. Annual mean sea surface temperature (BAH measurements) warmed by $1.1^{\circ} \mathrm{C}$ over
\end{abstract}

Communicated by H.-D. Franke

K. Reichert

Zoologisches Institut und Zoologisches Museum,

Martin-Luther-King-Platz 3, 20146, Hamburg, Germany

K. Reichert · F. Buchholz ( $\square)$

Biologische Anstalt Helgoland, Stiftung Alfred-Wegener Institut für Polar-und Meeresforschung, Box 180, 27483,

Helgoland, Germany

E-mail: fbuchholz@awi-bremerhaven.de

Tel.: +49-4725-819352

Fax: + 49-4725-819369 the past four decades. Range-related community shifts, introductions of non-indigenous species and the input of pollutants, are considered to explain long-term ecological changes in the invertebrate community at Helgoland.

Keywords Indications of change Invertebrate communities · Rocky intertidal · Helgoland ·

North Sea

\section{Introduction}

Intertidal communities are plastic systems as they change continuously in composition and abundance of organisms at several spatial and temporal scales (Dye 1998; Menconi et al. 1999). The exceptionally spatial and temporal variability in rocky shore communities arises from a combination of abiotic and biotic factors (Menge 1976, 1991; Lubchenco and Menge 1978; Underwood 1985; Menge and Sutherland 1987). Many studies have shown that intertidal communities are structured along gradients of abiotic factors, such as exposure to wave action and vertical tide level (e.g. Stephenson and Stephenson 1949, 1972; Southward 1958; Lewis 1978). To elucidate biotic influences, particularly manipulative experiments have led to an appreciation of the importance of species interactions, such as grazing, predation and competition, in spatial structuring of rocky shore communities (e.g. Dayton 1971; Paine 1974; Hawkins and Hartnoll 1985; Janke 1990; Jenkins et al. 1999; Leonard et al. 1999). Some studies have also shown that spatial and temporal variability in settlement and recruitment is important in establishing the mosaics associated with such communities (e.g. Harms and Anger 1983; Caffey 1985; Jenkins et al. 2000, 2001).

Although short-term, i.e. interannual to intra-decadal studies are indispensable to understand rocky shore community interactions, they mainly reflect the natural variability of parameters relevant to population dynamics. However, long-term investigations spanning 
several decades, are a prerequisite to analyse anthropogenic impacts on communities, and to differentiate these from short-term as well as long-term natural fluctuations in populations or communities at a specific site (Chiappone and Sullivan 1994). For example, changes in the abundance of macrobenthic species were related to predicted effects of recent climate warming (Beukema 1992; Barry et al. 1995; Southward et al. 1995; Sagarin et al. 1999). Furthermore, changes in the European littoral communities appear to coincide with the anthropogenic introduction of the Pacific oyster Crassostrea gigas during recent decades (de Kluijver 1997; Reise 1998; Wolff and Reise 2002).

Rocky shore communities are well suited for longterm ecological studies and are appropriate indicators for the status of the whole community or ecosystem. The limited locomotory potential, or fully sessile lifestyle, prevents the organisms to avoid short-term disturbances in the marine environment such as toxic algal blooms or long-term changes such as input and accumulation of harmful substances and nutrients, the introduction of alien species and climate change. Furthermore, rocky shore communities are usually well accessible, are clearly structured due to their overall two-dimensional nature and present lesser taxonomic problems than other ecosystems (Lewis 1976; Hartnoll and Hawkins 1980).

At Helgoland hard-bottom communities have been studied for more than a century (Harms 1993). Due to the relatively small extent of the Helgoland rocky littoral, covering about $35 \mathrm{~km}^{2}$, species composition as well as their spatial and temporal variability is relatively well recorded. At the same time, the rocky littoral of Helgoland is a marine protected area since 1981. Despite these facts, a comprehensive review of the invertebrate communities in the intertidal of Helgoland was only carried out by Janke (1986) and was not repeated since then. He documented species abundance, vertical zonation and its dynamics at a particular intertidal site during spring and summer of 1984 . The present study follows precisely the investigation by Janke (1986) and aims at a detailed comparison in order to reveal possible changes in the composition of invertebrate species over the past two decades. Furthermore, our study was intended to form a basis for a regular sampling scheme on a long-term schedule.

\section{Methods}

\section{Study site}

An intertidal site at Helgoland, German Bight, North Sea $\left(54^{\circ} 11^{\prime} \mathrm{N}, 7^{\circ} 55^{\prime} \mathrm{E}\right)$, previously sampled by Janke (1986), was re-surveyed. This site is located on a rocky abrasion platform in the north-eastern part of the island, known as "Nordostwatt" (Fig. 1). The area surrounding the "Nordostwatt" is described in Janke (1986) and detailed information about the surface morphology of the study site is given in Hagmeier (1930) and Janke
(1986). Janke (1986) described the algal and faunal community of the "Nordostwatt" as very sheltered with a typical pattern of distinct vertical zonation. Horizontal belts are described as the Enteromorpha-, the Mytilus-, the Fucus serratus- and the Laminaria-zone (Janke 1986, 1990; see Fig. 2). The "Nordostwatt" also includes several shallow subtidal channels, which extend in the northwest direction towards the open sea. The location features of each habitat and the dominant algal species are listed in Table 1. For a more detailed description of the algae biotopes on the abrasion platform see Bartsch and Tittley (2004).

\section{Survey methods}

Changes in the invertebrate community at the "Nordostwatt" were determined by comparing estimates of species abundance within the set of samples first surveyed by Janke in 1984 with estimates of abundance from the same set of samples re-surveyed in 2002. The original set of samples in 1984 is composed of nine different habitats which were reduced to five in 2002 . The selected habitats were unchanged in their structure since 1984, whereas the excluded ones were influenced by rocks, which occasionally fall from the vertical cliffs above.

These five habitats were the (1) Enteromorpha-, the (2) F. serratus-zone, the (3) channels, the (4) Laminariazone and individuals of (5) Laminaria digitata. As an additional habitat the Mytilus-zone was sampled in 2002. The Mytilus-zone had clearly dissociated as a separate zone from the $F$. serratus-zone, while in 1984 the Mytilus-beds were still inside the F. serratus-zone and were sampled as part of this zone.

The invertebrates within the six habitats were sampled every month from April until September 2002 using the techniques of data collection described by Janke (1986). The different structures within each habitat (e.g. rock pools, areas covered by sediment, visually dominant macroalgae) were sampled using different procedures. Rock pools and channels were sampled with a fine meshed hand net over a period of about $10 \mathrm{~min}$. Two litres of sediment as well as small pieces of rock were taken. Furthermore, 11 of smaller algal species (e.g. Enteromorpha species, Chondrus crispus) and 101 of large brown algae (e.g. F. serratus, Sargassum muticum) were collected. These samples were examined at the laboratory and the abundance of the invertebrates was estimated in the same way as species that could be readily identified with the unaided eye in the field.

The method of abundance estimation of the invertebrates in categories was taken from Janke (1986; see Table 2). The categorization of the invertebrates according to conspicuousness is subjective to a certain extent. In order to reduce the subjectivity, an on-site comparison of the categorization of the species was performed over 2 days with Dr. Janke in person until a close match in results was achieved. 


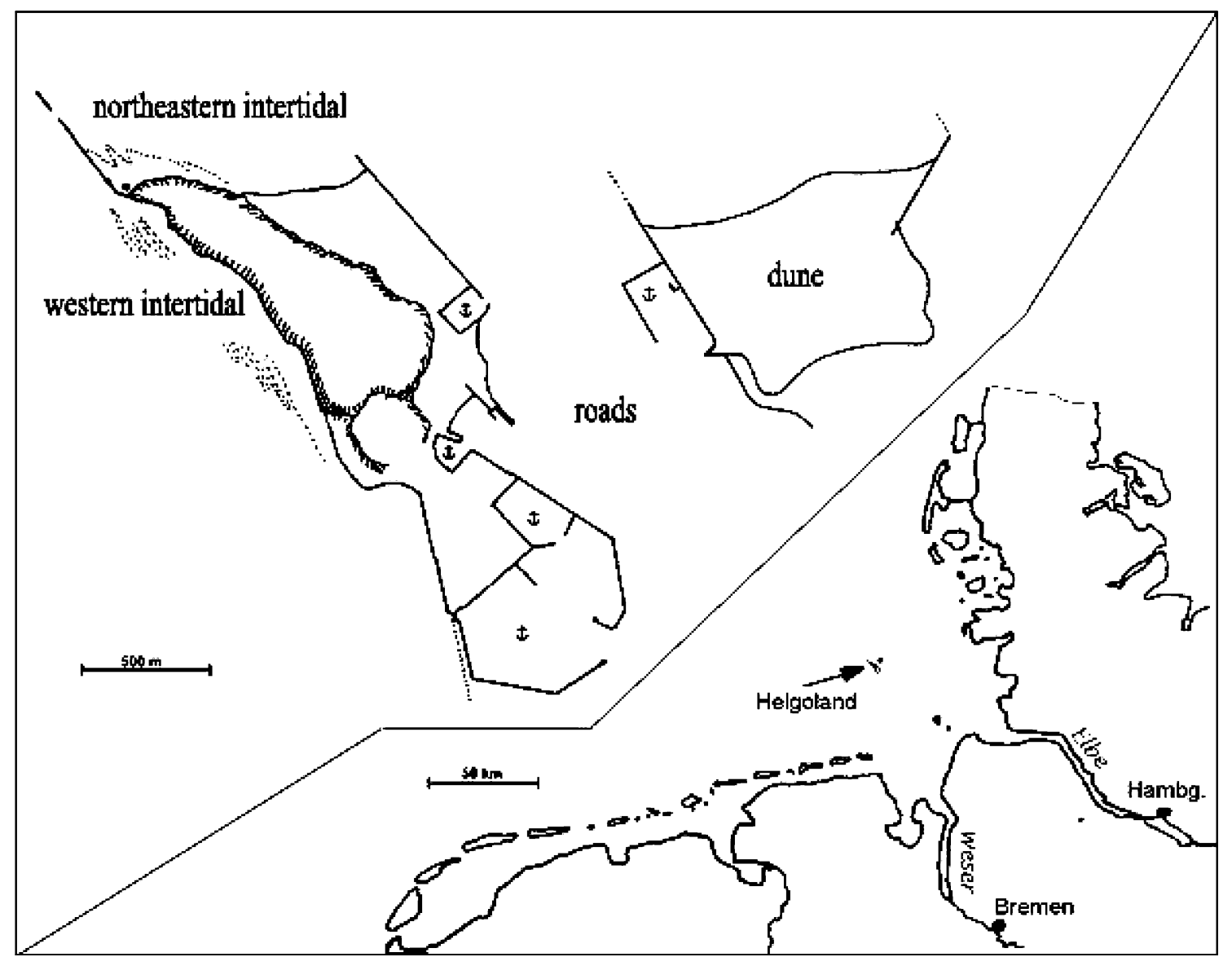

Fig. 1 The study site in the north-eastern part of Helgoland, and the island's location in the North Sea (according to Benoit 1996, unpublished)

Fig. 2 Aerial picture of the abrasion platform of the "Nordostwatt" of Helgoland (land survey office of Schleswig-Holstein). The investigated zones are marked

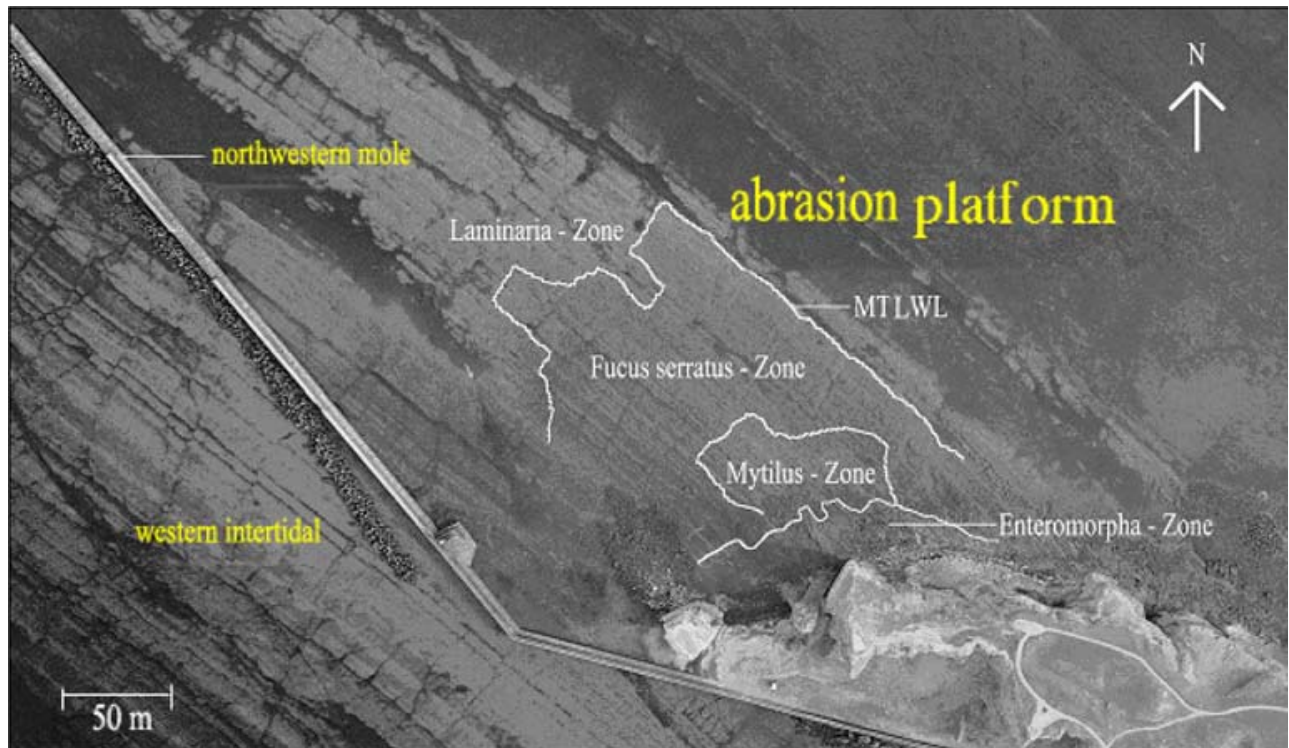

Although Janke did not quantify algal cover, he provided qualitative accounts of conspicuous algae which were also qualitatively sampled within each habitat in 2002.
Data analysis

Some of the species names, which were identified in Janke's study, were updated based on subsequent taxo- 
Table 1 The location features (mean period of emersion during one tide in hours; parallel and perpendicular extension to the coastline in metres) and dominating algal species of the six habitats of the abrasion platform

\begin{tabular}{|c|c|c|c|c|c|}
\hline \multirow[t]{2}{*}{ Vertical belt } & \multicolumn{4}{|c|}{ Location features } & \multirow[t]{2}{*}{ Dominant algal species } \\
\hline & Zone & $\begin{array}{l}\text { Mean period } \\
\text { of emersion }\end{array}$ & $\begin{array}{l}\text { Parallel } \\
\text { extension }\end{array}$ & $\begin{array}{l}\text { Perpendicular } \\
\text { extension }\end{array}$ & \\
\hline Enteromorpha-zone & $\begin{array}{l}\text { High } \\
\text { intertidal }\end{array}$ & ca. 6 & ca. $15-40$ & ca. $50-60$ & $\begin{array}{l}\text { Enteromorpha spp., Ulva spp., } \\
\text { Ulothrix/Urospora spp., Fucus serratus }\end{array}$ \\
\hline $\begin{array}{l}\text { Mytilus } \\
\text { edulis-zone }\end{array}$ & $\begin{array}{l}\text { Mid } \\
\text { intertidal }\end{array}$ & ca. 4 & ca. $35-80$ & ca. $60-70$ & $\begin{array}{l}\text { Seasonal species (e.g. Cladophora sericea, } \\
\text { Monostroma spp., Rhizoclonium tortuosum, } \\
\text { Dumontia contorta), F. serratus, } \\
\text { Fucus vesiculosus, Ralfsia verrucosa, } \\
\text { Chondrus crispus, Mastocarpus stellatus, } \\
\text { Phymatholithon spp. }\end{array}$ \\
\hline $\begin{array}{l}\text { Fucus } \\
\text { serratus-zone }\end{array}$ & $\begin{array}{l}\text { Low } \\
\text { intertidal }\end{array}$ & ca. 2.5 & ca. $100-210$ & ca. $60-150$ & $\begin{array}{l}\text { Cladophora rupestris, F. serratus, C. crispus, } \\
\text { Corallina officinalis, Phymatholithon spp. }\end{array}$ \\
\hline Channels & $\begin{array}{l}\text { Shallow } \\
\text { subtidal }\end{array}$ & $\begin{array}{l}\text { Permanently submerged } \\
\text { except for short times } \\
\text { during extreme } \\
\text { spring tides }\end{array}$ & - & ca. 3-5 & $\begin{array}{l}\text { Ulva spp., seasonal species } \\
\text { (e.g. Cladophora spp., Rhizoclonium } \\
\text { tortuosum), Sargassum muticum, } \\
\text { Laminaria digitata, F. serratus, } \\
\text { C. officinalis, C. crispus, } \\
\text { Phymatholithon spp. }\end{array}$ \\
\hline Laminaria-zone & Subtidal & (see channels) & From ca. 230 & - & $\begin{array}{l}\text { Ulva spp., C. rupestris, L. digitata, } \\
\text { F. serratus, C. officinalis, C. crispus, } \\
\text { Phymatholithon spp. }\end{array}$ \\
\hline
\end{tabular}

nomic revisions. In a few cases, taxonomic changes required unification of recent species. For example, the abundance of the sponge Sycon ciliatum in the investigation of 2002 was compared to those of $S$. coronatum in Janke's study. The two species are united as $S$. ciliatum (van Soest 2001).

Species of which the taxonomic position is tentative were combined to a complex. An example is the mussel Hiatella rugosa which was regarded as a complex with $H$. arctica by Willmann (1989). Furthermore, some species were combined into a complex if the morphological distinctions between two species were difficult to quantify or too time consuming to investigate. For example, the definite taxonomic differentiation between

Table 2 Categories of species conspicuousness

\begin{tabular}{ll}
\hline $\begin{array}{l}\text { Category of } \\
\text { conspicuousness }\end{array}$ & Definition
\end{tabular}

conspicuousness

\begin{tabular}{ll}
\hline Absence (0) & No specimens found \\
Occasional (1) & Only 1 or 2 specimens found \\
Rare (2) & A few (3-5) specimens found, \\
& widely scattered over the study area \\
Regular (3) & Specimens occurring regularly (6-20) \\
at short-distances without forming & colonies or aggregations \\
Specimens in all samples, forming \\
small or medium size colonies \\
or aggregations \\
Specimens in all samples, conspicuous \\
at first glance, forming large colonies \\
or aggregations \\
Sessile specimens dominating the area \\
and displacing most other \\
species from it
\end{tabular}

the bryozoans Alcyonidium gelatinosum and A. mytili involves electrophoresis, and between the periwinkle Littorina mariae and L. obtusata requires preparation of the penis (Hayward 1985; Willmann 1989).

Due to taxonomic ambiguities, three species (Didemnum spec. ('84 and '02), Sagartiogeton spp. ('02), Schizoporella spp. ('02) and ('84) were eliminated from further analysis. The hydrozoans Clytia hemisphaerica and Kirchenpaueria pinnata were excluded from the comparison because these two species occurred only on the introduced Japanese seaweed S. muticum that was selected as an additional sample in 2002 (see above).

Presence and absence of species as well as species conspicuousness were compared between the investigations. For all taxonomic groups, the proportion of species additions (species present only in the latter study) and losses (present only in the former study) as well as the proportion of increases (species conspicuousness higher in the latter study) and decreases (lower in the latter study) were compared, except for cases of taxonomic ambiguities.

For multivariate analysis the PRIMER software package from Plymouth Marine Laboratory (PML), UK was used. Cluster analysis and multi-dimensional scaling was carried out on the semi-quantitative data (categories of conspicuousness; Table 2) of all invertebrates (except for eliminated species; see above). The classification and ordination technique based on nontransformed data using the Bray-Curtis index and the average linkage method for clustering was applied. The mean species abundances of the sampling months were considered, so that the data matrix consists of 186 invertebrates and 11 samples (five habitats in both sampling years plus Mytilus-zone surveyed only in 
Table 3 Changes in 186 species used for semi-quantitative comparison between 1984 and 2002 (average conspicuousness is calculated over the sampled habitats and months of the respective year; for definition of categories, see Table 2)

\begin{tabular}{|c|c|c|}
\hline \multirow[t]{2}{*}{ Species } & \multicolumn{2}{|c|}{$\begin{array}{l}\text { Average } \\
\text { conspicuousness }\end{array}$} \\
\hline & 1984 & 2002 \\
\hline \multicolumn{3}{|l|}{ Porifera } \\
\hline Halichondria panicea & 3 & 3 \\
\hline Halisarca dujardini & 1 & 2 \\
\hline Leucosolenia botryoides & 1 & 2 \\
\hline Sycon ciliatum & 1 & 1 \\
\hline \multicolumn{3}{|l|}{ Cnidaria } \\
\hline Actinia equina & 1 & 1 \\
\hline Aurelia aurita & 1 & 1 \\
\hline Clava multicornis & 2 & 1 \\
\hline Coryne pusilla & 1 & 1 \\
\hline Craterolophus convolvulus & 1 & 1 \\
\hline Dynamena pumila & 3 & 3 \\
\hline Eudendrium rameum & 1 & 1 \\
\hline Halecium tenellum & 0 & 1 \\
\hline Haliclystus auricula & 0 & 1 \\
\hline Hartlaubella gelatinosa & 1 & 1 \\
\hline Hydrallmania falcata & 1 & 1 \\
\hline Laomedea flexuosa & 2 & 2 \\
\hline Metridium senile & 1 & 1 \\
\hline Obelia geniculata & 1 & 1 \\
\hline Plumularia setacea & 0 & 1 \\
\hline Sagartia elegans & 1 & 1 \\
\hline Sagartia troglodytes & 1 & 1 \\
\hline Sagartiogeton laceratus & 1 & 0 \\
\hline Sagartiogeton undatus & 1 & 1 \\
\hline Sertularia cupressina & 1 & 1 \\
\hline Urticina felina & 1 & 1 \\
\hline \multicolumn{3}{|l|}{ Nemertea } \\
\hline Amphiporus lactifloreus & 1 & 0 \\
\hline Cephalothrix rurifrons & 1 & 1 \\
\hline Emplectonema gracile & 1 & 0 \\
\hline Lineus bilineatus & 1 & 1 \\
\hline Lineus ruber & 2 & 1 \\
\hline Lineus viridis & 1 & 0 \\
\hline Micrura fasciolata & 1 & 0 \\
\hline Oerstedia dorsalis & 1 & 1 \\
\hline Procephalothrix filiformis & 1 & 0 \\
\hline Tetrastemma candidum & 1 & 1 \\
\hline Tetrastemma vermiculus & 1 & 1 \\
\hline \multicolumn{3}{|l|}{ Polyplacophora } \\
\hline Lepidochitona cinerea & 2 & 1 \\
\hline Lepidochiton asellus & 1 & 0 \\
\hline \multicolumn{3}{|l|}{ Gastropoda } \\
\hline Acanthodoris pilosa & 1 & 1 \\
\hline Acmaea virginea & 1 & 0 \\
\hline Aeolidia papillosa & 1 & 0 \\
\hline Archidoris pseudoargus & 1 & 0 \\
\hline Buccinum undatum & 1 & 1 \\
\hline Calliostoma zizyphinum & 1 & 0 \\
\hline Cuthona foliata & 0 & 1 \\
\hline Dendronotus frondosus & 1 & 0 \\
\hline Doto coronata & 1 & 0 \\
\hline Elysia viridis & 0 & 1 \\
\hline Epitonium clathrus & 0 & 1 \\
\hline Facelina auriculata & 1 & 1 \\
\hline Flabellina pedata & 1 & 0 \\
\hline Flabellina verrucosa & 1 & 1 \\
\hline Gibbula cineraria & 3 & 4 \\
\hline Hydrobia ulvae & 2 & 2 \\
\hline
\end{tabular}

Table 3 (Contd.)

Species

Average

conspicuousness

\begin{tabular}{lll} 
& 1984 & 2002 \\
\hline Lacuna pallidula & 2 & 3 \\
Lacuna vincta & 2 & 2 \\
Lamellaria perspicua & 0 & 1 \\
Limapontia capitata & 0 & 1 \\
Limapontia senestra & 0 & 1 \\
Littorina littorea & 2 & 2 \\
Littorina mariae/L. obtusata (complex) & 2 & 4 \\
Littorina saxatilis & 1 & 1 \\
Nucella lapillus & 1 & 0 \\
Onchidoris muricata & 1 & 0 \\
Onoba aculeus & 2 & 1 \\
Polycera quadrilineata & 1 & 1 \\
Pusillina inconspicua & 1 & 1 \\
Raphitoma linearis & 0 & 1 \\
Retusa truncatula & 1 & 0 \\
Rissoa parva & 1 & 1 \\
Skeneopsis planorbis & 1 & 0
\end{tabular}

Bivalvia

Anomia ephippium

Hiatella arctica/H. rugosa (complex)

Mytilus edulis

Pholas dactylus

Venerupis pullastra

Sipuncula

Golfingia minuta

1

Kamptozoa

Pedicellina cernua

Annelida (Polychaeta and Oligochaeta)

Aphelochaeta multibranchiis

Autolytus prolifera

Capitella giardi

Circeis spirillum

Dodecaceria concharum

Eulalia viridis

Eumida sanguinea

Fabricia sabella

Gattyana cirrosa

Harmothoe imbricata

Harmothoe impar

Janua pagenstecheri

Lanice conchilega

Lepidonotus squamatus

Malacoceros fuliginosus

Microphthalmus sczelkowii

Neoamphitrite figulus

Nereis diversicolor

Nereis pelagica

Nereis virens

Nicolea zostericola

Ophryotrocha gracilis

Paranais litoralis

Phyllodoce maculata

Polydora ciliata

Pomatocerus triqueter

Sabellaria spinulosa

Scolelepis squamata

Spirorbis corallinae

Spirorbis spirorbis

Spirorbis tridentatus

Sthenelais boa

Syllides articulocirratus

Syllis gracilis 
Table 3 (Contd.)

\begin{tabular}{|c|c|c|}
\hline \multirow[t]{2}{*}{ Species } & \multicolumn{2}{|c|}{$\begin{array}{l}\text { Average } \\
\text { conspicuousness }\end{array}$} \\
\hline & 1984 & 2002 \\
\hline Tubificoides benedii & 0 & 1 \\
\hline Typosyllis armillaris & 1 & 1 \\
\hline \multicolumn{3}{|l|}{ Pantopoda } \\
\hline Achelia hispida & 1 & 1 \\
\hline Anoplodactylus angulatus & 1 & 0 \\
\hline Nymphon rubrum & 1 & 0 \\
\hline Phoxichilidium femoratum & 1 & 1 \\
\hline Pycnogonum littorale & 1 & 1 \\
\hline \multicolumn{3}{|l|}{ Crustacea } \\
\hline Aora typica & 0 & 1 \\
\hline Apherusa bispinosa & 1 & 1 \\
\hline Apherusa jurenei & 1 & 1 \\
\hline Athanas nitescens & 0 & 1 \\
\hline Balanus balanus & 1 & 1 \\
\hline Balanus crenatus & 2 & 2 \\
\hline Bodotria scorpioides & 1 & 1 \\
\hline Calliopius laeviusculus & 1 & 2 \\
\hline Cancer pagurus & 1 & 1 \\
\hline Caprella linearis & 1 & 1 \\
\hline Carcinus maenas & 3 & 3 \\
\hline Chaetogammarus marinus & 1 & 2 \\
\hline Cheirocratus sundevallii & 1 & 1 \\
\hline Corophium insidiosum & 2 & 1 \\
\hline Crangon allmanii/C. crangon (complex) & 1 & 1 \\
\hline Dexamine spinosa & 1 & 2 \\
\hline Dexamine thea & 1 & 1 \\
\hline Elminius modestus & 1 & 2 \\
\hline Galathea squamifera & 1 & 1 \\
\hline Gammarellus homari & 0 & 1 \\
\hline Gammarus locusta & 0 & 1 \\
\hline Hyale nilssoni & 1 & 1 \\
\hline Hyas araneus & 1 & 1 \\
\hline Idotea baltica & 0 & 1 \\
\hline Idotea chelipes & 0 & 1 \\
\hline Idotea granulosa & 2 & 3 \\
\hline Jaera albifrons & 2 & 1 \\
\hline Jassa falcata & 3 & 3 \\
\hline Jassa marmorata & 0 & 1 \\
\hline Ligia oceanica & 0 & 1 \\
\hline Liocarcinus holsatus & 1 & 1 \\
\hline Melita palmata & 1 & 1 \\
\hline Pagurus bernhardus & 2 & 2 \\
\hline Palaemon elegans & 0 & 1 \\
\hline Pandalina brevirostris & 1 & 0 \\
\hline Pilumnus hirtellus & 2 & 1 \\
\hline Pisidia longicornis & 1 & 1 \\
\hline Semibalanus balanoides & 1 & 1 \\
\hline Verruca stroemia & 2 & 3 \\
\hline \multicolumn{3}{|l|}{ Insecta } \\
\hline Anurida maritima & 1 & 1 \\
\hline Clunio marinus & 1 & 1 \\
\hline Petrobius brevistylis & 1 & 0 \\
\hline \multicolumn{3}{|l|}{ Bryozoa } \\
\hline Alcyonidium mytili/A. gelatinosum (complex) & 2 & 2 \\
\hline Bowerbankia gracilis & 1 & 1 \\
\hline Bowerbankia imbricata & 0 & 1 \\
\hline Bowerbankia pustulosa & 1 & 1 \\
\hline Callopora lineata & 1 & 1 \\
\hline Celleporella hyalina & 1 & 1 \\
\hline Cibrilina punctata & 1 & 0 \\
\hline Conopeum reticulum & 1 & 1 \\
\hline Cryptosula pallasiana & 2 & 2 \\
\hline
\end{tabular}

Table 3 (Contd.)

\begin{tabular}{lll}
\hline Species & \multicolumn{2}{l}{$\begin{array}{l}\text { Average } \\
\text { conspicuousness }\end{array}$} \\
\cline { 2 - 3 } \cline { 2 - 2 } & 1984 & 2002 \\
\hline Electra pilosa & 3 & 3 \\
Escharella immersa & 1 & 1 \\
Escharella variolosa & 1 & 1 \\
Flustrellidra hispida & 2 & 2 \\
Membranipora membranacea & 1 & 1 \\
Schizoporella errata & 1 & 1 \\
Walkeria uva & 1 & 1 \\
Echinodermata & & \\
Amphipholis squamata & 2 & 2 \\
Asterias rubens & 1 & 1 \\
Psammechinus miliaris & 1 & 1 \\
Ascidiae & & \\
Botrylloides leachi & 1 & 1 \\
Botryllus schlosseri & 2 & 3 \\
Clavelina lepadiformis & 1 & 2 \\
Molgula citrina/M. complanata (complex) & 1 & 1 \\
Polyclinum aurantium & 0 & 1 \\
Sidnyum turbinatum & 2 & 3 \\
\hline
\end{tabular}

2002). Two arbitrary similarity values were chosen at a spread of hierarchical levels to determine particular groupings of samples.

\section{Results}

Changes in presence and absence

A total of 154 species in 24 taxonomic groups were found in 2002. Janke, by contrast, found 158 species in 25 taxonomic groups in the same habitats. 126 species appeared in both studies. 28 species were only found in 2002, whereas 32 species were recorded only in the former study (Table 3; Fig. 3).

Within the gastropod molluscs (22 species in 2002; 26 species in 1984) the proportion of species lost and added was particularly high with $54.5 \%$ between both years. Of 33 gastropod species compared seven species were newly recorded in 2002 and eleven had disappeared. The polychaetes and oligochaetes (29 species in 2002; 31 species in 1984) showed conspicuous changes in the proportion of species lost and added. A change of $36.8 \%$ was noted. Six of 38 annelids newly occured in 2002, and eight species were not found any more. The annelids were followed by crustaceans $(25.6 \%)$ which was the group with the highest number of species in 2002 (38 species in 2002; 30 species in 1984). Nine of 38 crustacean species newly appeared during the present study, and only one was missing between surveys. The taxonomic group of the kamptozoans was not found during 2002.

Changes in species conspicuousness

A considerable change in species conspicuousness was recorded in the group of crustaceans (Table 3). About 
Fig. 3 Macrofauna of the rocky intertidal of Helgoland: changes in presence/absence of all species recorded in 1984 and/or 2002 in the sampling area. "Both studies" are species recorded in 2002 and 1984. "Additions" are species recorded in the present study, but not in 1984. "Losses" are species recorded in the latter study, but not in 2002

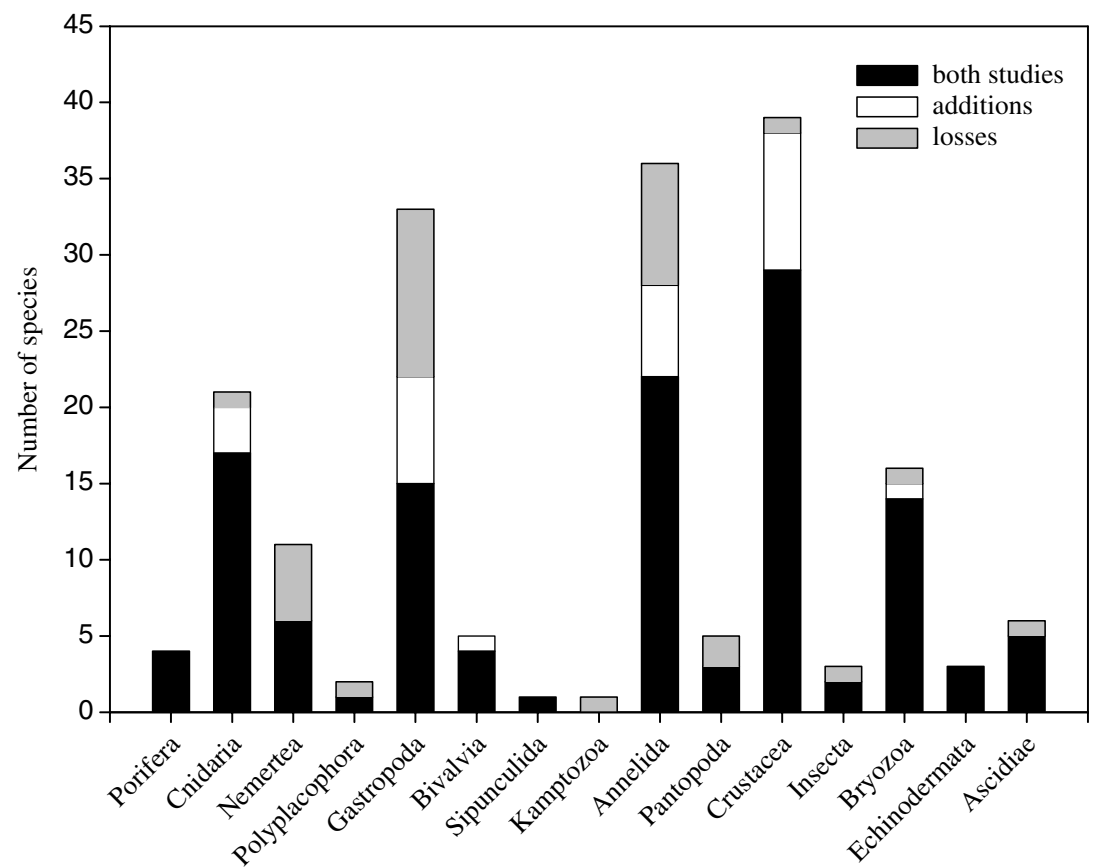

$20.7 \%$ increased in conspicuousness, and $10.3 \%$ decreased between surveys. The crustaceans were followed by gastropods with $20 \%$ increase and $6.7 \%$ decrease in conspicuousness. None of the ascidian species decreased in conspicuousness between 1984 and 2002, but three out of five ascidian species increased.

\section{Multivariate analysis}

In the dendrogram three main groups can be distinguished at the $50 \%$ similarity level (Fig. 4). These groups $(\mathrm{A}-\mathrm{C})$ show different zones which are grouped together due to fundamentally different communities at different tidal heights. The first group (A) consists of samples gathered in the lower intertidal zones $(F$. serratus-, Laminaria-zone, channels, $L$. digitata) over the whole sampling period in 1984 and 2002. The second group (B) is represented by the mid intertidal (Mytiluszone) sampled in 2002, and the third group (C) combines samples gathered in the high intertidal zone (Enteromorpha-zone) during both study periods.

At the $70 \%$ similarity level four sub-groups within group $\mathrm{A}$, and two sub-groups within group $\mathrm{C}$ are formed (Fig. 4). These sub-groups show a splitting according to the two sampling years. Groups which are combined
Fig. 4 Dendrogram of the five habitats surveyed in 1984 and 2002, plus the Mytilus-zone sampled only in 2002, using group-average clustering from Bray-Curtis similarity on nontransformed data. The groups distinguished at the $50 \%$ similarity threshold (continuous line) are marked $\mathrm{A}-\mathrm{C}$, and the sub-groups distinguished at the $70 \%$ similarity threshold (dashed line) are marked 1A4A, 1C and 2C. (Ent Enteromorpha-, Myt Mytilus edulis-, Fuc Fucus serratus-zone, chan channels, L. dig Laminaria digitata, Lam Laminaria-zone)

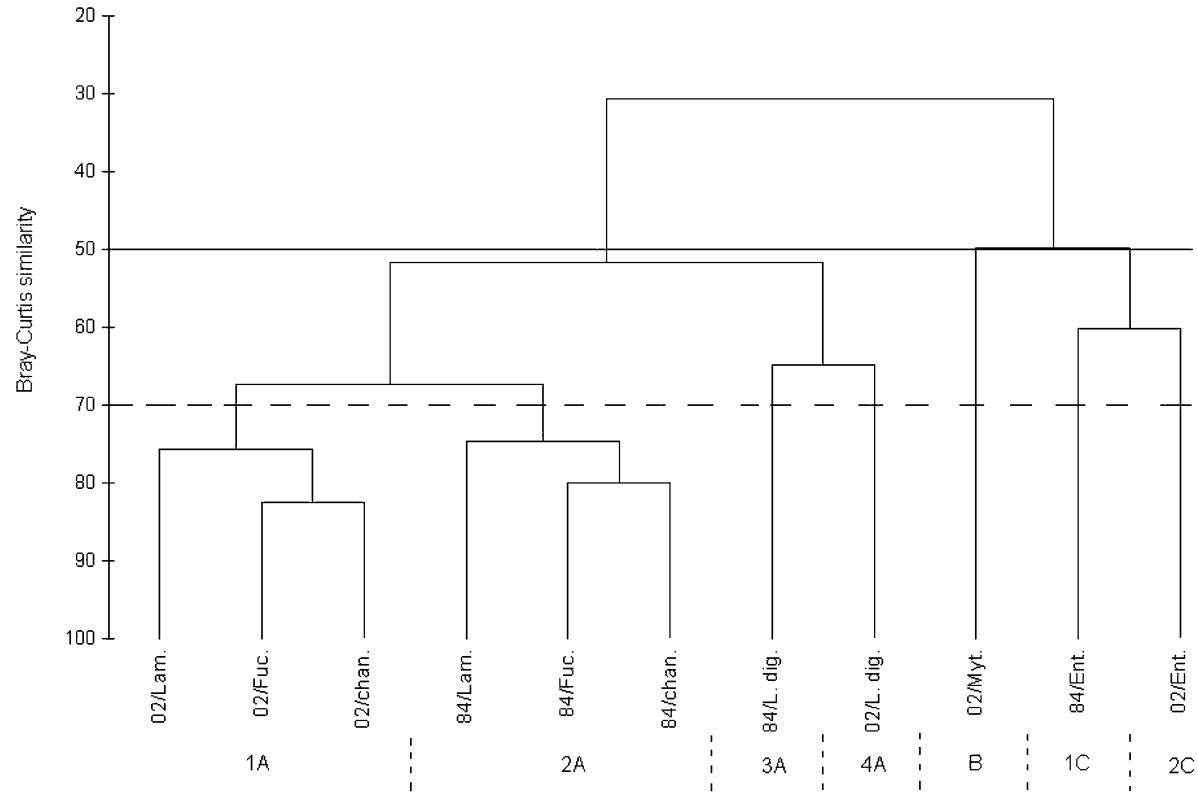


owing to different communities in 2002 and 1984 are clear in 1A (lower intertidal zones in 2002) and 2A (lower intertidal zones in 1984) where the F. serratus-, L. digitata-zone and channels of 1 year can be regarded as replicates and are more similar to each other than one particular zone of the lower intertidal over both study years. These two sets of groupings are superimposed on the MDS ordination (stress value: 0.05; results not shown).

\section{Changes in algal cover}

In the present study the brown alga $S$. muticum dominated in biomass in the channels, forming conspicuous floating fields. The red alga Mastocarpus stellatus was a prominent species in the Mytilus-zone. None of these species were present in 1984.

In contrast, the brown algae $F$. serratus which dominated the mid and lower intertidal zone in 1984 did not form abundant stands in the Mytilus-zone of the abrasion platform in 2002. Halidrys siliquosa, which was sampled in the Laminaria-zone in 1984, did not form stands during the whole investigation in 2002 any more. Only single scattered specimens were found.

\section{Discussion}

The temporal comparison revealed the most pronounced changes within the molluscs, the annelids and the crustaceans (Table 3; Fig. 3). The numerical changes in these three taxonomic groups were to be expected as those groups contained the highest number of species. On closer examination of species within the taxonomic groups it appeared that species, which occurred only in one year, were species which were classified as "occasional" in average conspicuousness. However, some species with low abundance were those which live near their limit of distribution and were subjected to strongly variable environmental conditions, e.g. in temperature. Accordingly, those species should not be neglected when compared to abundant ones, although there is a necessity for critical consideration of rare species which are easily overlooked, particularly when species are small and inconspicuous.

The cluster analysis showed spatial as well as temporal differences in the invertebrate communities of the abrasion platform. During the recent decades many investigations demonstrated a distinct pattern of vertical zonation due to fundamentally different composition of species in the high, mid and low intertidal zone in rocky shore communities (e.g. Stephenson and Stephenson 1949, 1972; Crisp and Southward 1958; Southward 1958; Menge 1976; Lewis 1978). Accordingly, a grouping of different zones with different invertebrate assemblages at different intertidal heights was to be expected (Fig. 4).

More interesting were the differences in the invertebrate communities between Janke's study in 1984 and the present one in 2002 . Here, the most obvious changes occurred in the lower intertidal (Fig. 4). This is important because the lower intertidal spans about threequarters of the area sampled (Table 1; Fig. 2). In the following discussion, changes in the communities of the lower intertidal between the sampling years are described on the basis of examples and linked to temperature change, introduction of non-indigenous species and the effects of pollutants. In this context, massive changes in the composition of macroalgae assemblages found on the abrasion platform are also discussed.

A warming trend of the North Sea was first indicated by Becker and Pauly (1996). A precise record is the Helgoland Roads time series, which showed an annual mean sea surface temperature increase of $1.13^{\circ} \mathrm{C}$ for the 40 years since 1962 (Wiltshire and Manley 2004).

The presence and absence of gastropod molluscs changed markedly between both years. Especially some sea slugs, such as Aeolidia papillosa and Dendronotus frondosus, were absent in the present study. These species normally live permanently submerged (Thompson 1988), and are thus limited in occurrence in a tidal area. Furthermore, Meyer (1971) reported that nudibranchs (e.g. A. papillosa and D. frondosus) of the Atlantic coast of North America are cold stenotherms with regard to their reproductive phase. In spring 1984 as well as in the summer months these sea slugs were found in shallow subtidal areas at the study site. In contrast, in 2002 these species were observed only in deeper subtidal areas around Helgoland. However, in dredge samples from the Tiefe Rinne (deep channel, maximum $60 \mathrm{~m}$ ) immediately south of Helgoland, these sea slugs were numerous (Schubert personal communication). This may indicate that the appearance of the sea slugs is limited by high temperatures which frequently predominate in intertidal sites. Furthermore, we recorded the warm adapted sea slug Elysia viridis for the first time in the intertidal and its appearance may be related to recent climate anomalies (Franke and Gutow 2004).

The increased conspicuousness of the "southern" sea squirt Botryllus schlosseri in the present study may also be related to the current increase in mean water temperatures. As a matter of fact, in a former survey carried out at Helgoland harbour, low resistance to low winter temperatures was detected in this species (Harms and Anger 1983). Generally, the mild winter temperatures in the last decade seem to be one of the decisive factors that favour species immigration from milder areas of the Atlantic Ocean to the North Sea. Such a northward shift of southern species and/or a retreat northwards of northern species is one factor, which causes changes in the distribution and abundance of species (e.g. Beukema 1992; Southward et al. 1995; Edwards et al. 1999; Franke and Gutow 2004; Hiscock et al. 2004).

Another factor is the anthropogenic introduction of alien species whose settlement and recruitment success may be enhanced by temperature increases. There are well known examples of alien species, which profit from climate change and often cause abundance changes in 
the native community (e.g. Franke et al. 1999; Walther et al. 2002; Drinkwaard 1999; Diederich et al. 2004).

An example for the intertidal of Helgoland are two space competitors, the indigenous barnacle Semibalanus balanoides and the alien Elminius modestus, which was first recorded at Helgoland in 1954 (Den Hartog 1959). Their interaction is strongly influenced by physical factors, especially temperature, which affects the breeding period, settlement, recruitment and mortality rate and change in the abundance of the two competitors is the consequence (Crisp 1964; Moyse and Nelson-Smith 1964; Southward et al. 1995; Franke and Gutow 2004). Such change in abundance also appeared in the present study. E. modestus increased in conspicuousness, whereas $S$. balanoides did not change. Currently, $E$. modestus dominates the barnacle community in the upper zones of the northeastern intertidal of Helgoland (Wendt personal communication).

Exotic species appear to particularly profit from climate induced effects causing changes in the distribution and abundance of the rocky shore community. However, some changes recorded here may also be indicative of pollutant influences. During the study in 1984, Nucella lapillus appeared in small numbers (Janke 1986). In 2002 , only two individuals of $N$. lapillus were found outside the routine sampling area. The prosobranch $N$. lapillus is generally regarded as one of the most sensitive species, which becomes sterile at even low TBT-concentrations (Gibbs et al. 1988; Birchenough et al. 2002). It is known that the TBT contaminations of the surface water around Helgoland did not change considerably between the application ban of the use of anti-fouling paints for small vessels and the end of the 1990s (Watermann 1993; Kalbfus 1997). Therefore, it may be possible that the prevailing TBT concentrations are responsible for the decrease of $N$. lapillus at Helgoland between the study in 1984 and 2002.

Although neither study did consider algal species as thoroughly as invertebrates, massive changes in the composition of macroalgae were obvious. Conspicuous and major changes which took place after 1984 are the extensive settlement of the marine benthic macroalgae $S$. muticum and $M$. stellatus as well as the decrease of F. serratus in the Mytilus-zone (see Fig. 2). Less conspicuous though substantial is the decrease in the alga $H$. siliquosa in the upper Laminaria-zone.

The first record, the spread and the present occurrence of S. muticum and M. stellatus around Helgoland were reported by Kornmann and Sahling (1994), Bartsch and Kuhlenkamp (2000) and Bartsch and Tittley (2004). The reduction of $H$. siliquosa to scattered singular stands in the present study may be related to a replacement by $S$. muticum in submerged areas of the platform. That S. muticum competes with seaweeds and causes a significant decrease in the settlement of slowly growing and several year old algae, particularly in H. siliquosa, was shown by Stæhr et al. (2000).

The decrease of the brown alga $F$. serratus in the Mytilus-zone which happened between winter 1984/1985 and 1985/1986 (Janke 1986, 1990) may have been caused by a series of cold winters in the mid 1980s and particularly by freezing and following detachment of $F$. serratus blades by tidal currents and wave action. The recovery of dense $F$. serratus stands was probably prevented by biotic factors such as increased grazing of littorinids which may have prevented a settlement of Fucus species. Furthermore, an inhibited pressure of predation by $N$. lapillus may have led to an increased abundance of mussels, which in turn compete with brown algae. Such effects could be shown in several studies on population dynamics in rocky shore communities (e.g. Menge 1976; Menge and Sutherland 1976; Lubchenco 1983). However, to assess the natural variation of $F$. serratus stands in the Mytilus-zone due to a combination of physical and biotic factors a long-term study would be needed at Helgoland.

Finally, this study clearly shows that snapshots at two points in time can be used to indicate changes which may essentially be anthropogenic. However, it is difficult to obtain clear evidence that such medium-term change is dependent on man-induced factors and does not reflect natural cycles with a periodicity of decades. Particularly in the observation and understanding of non-seasonal cycles, due to complex interactions of abiotic and biotic factors in many cases, it is important to differentiate these from man-induced fluctuations in communities. To detect natural variation in seasonal cycles from year to year and to relate the medium-term changes to possible a-seasonal cycles, continued monitoring is necessary (Hartnoll and Hawkins 1980; Hawkins and Hartnoll 1983; Southward 1995). The current study was intended to help to create a baseline for further regular sampling using accepted quantitative methods. These studies may support appropriate measures in the management of the rocky shore communities around Helgoland in view of the area being a marine protected area and a reference site for European ecological comparisons.

Acknowledgements This work contains parts of the diploma thesis of K. Reichert partly conducted at the Zoological Institute and Museum of the University of Hamburg (Prof. Dr. C.D. Zander). We gratefully acknowledge the help of Dr. K. Janke of the "Behörde für Umwelt und Gesundheit Hamburg" and Dr. I. Bartsch of the Foundation Alfred-Wegener Institute of Polar and Marine Research. For help with the identification of species, we thank Dr. H.-G. Andres (amphipods), Dr. B. Hilbig (polychaetes) and Dr. G. Jarms (hydrozoans) of the Zoological Institute and Museum of the University of Hamburg.

\section{References}

Barry JP, Baxter CH, Sagarin RD, Gilman SE (1995) Climaterelated, long-term faunal change in a California rocky intertidal community. Science 267:672-675

Bartsch I, Kuhlenkamp R (2000) The marine macroalgae of Helgoland (North Sea): an annotated list of records between 1845 and 1999. Helgol Mar Res 54:160-189

Bartsch I, Tittley I (2004) The rocky intertidal biotopes of Helgoland: present and past. Helgol Mar Res 58:289-302

Becker GA, Pauly M (1996) Sea surface temperature changes in the North Sea and their causes. ICES J Mar Sci 53:887-898 
Beukema JJ (1992) Expected changes in the Wadden sea benthos in a warmer world: lessons from periods with mild winters. Neth J Sea Res 30:73-79

Birchenough AC, Evans SM, Moss C, Welch R (2002) Re-colonisation and recovery of populations of dogwhelks Nucella lapillus (L.) on shores formerly subject to severe TBT contamination. Mar Poll Bull 44:652-659

Caffey HM (1985) Spatial and temporal variation in settlement and recruitment of intertidal barnacles. Ecol Monogr 55:313-332

Chiappone M, Sullivan KM (1994) Ecological structure and dynamics of nearshore hard-bottom communities in the Florida keys. Bull Mar Sci 54:747-756

Crisp DJ (1964) Mortalities in marine life in North Wales during the winter of 1962-63. In: Crisp DJ (ed) The effects of the severe winter of 1962-63 on marine life in Britain. J Anim Ecol 33:190-197

Crisp DJ, Southward AJ (1958) The distribution of intertidal organisms along the coasts of the English channel. J Mar Biol Assoc UK 37:157-208

Dayton PK (1971) Competition, disturbance, and community organization: the provision and subsequent utilization of space in a rocky intertidal community. Ecol Monogr 41:351-389

De Kluijver MJ (1997) Sublittoral communities of North Sea hardsubstrata. Print Partners Ipskamp, Enschede

Den Hartog C (1959) Die Seepocke Elminius modestus auf Helgoland. Beaufortia 7:207-209

Diederich S, Nehls G, Beusekom JEE V, Reise K (2004) Introduced Pacific oysters (Crassostrea gigas) in the northern Wadden Sea: invasion accelerated by warm summers? Helgol Mar Res 59:97-106

Drinkwaard AC (1999) Introductions and developments of oysters in the North Sea area: a review. Helgol Meeresunters 52:301-308

Dye AH (1998) Dynamics of rocky intertidal communities: analyses of long time series from South African shores. Estuar Coast Shelf Sci 46:287-305

Edwards M, John AWG, Hunt HG, Lindley JA (1999) Exceptional influx of oceanic species into the North Sea late 1997. J Mar Biol Assoc UK 79:737-739

Franke HD, Gutow L (2004) Long-term changes in the macrozoobenthos around the rocky island of Helgoland (German Bight, North Sea). Helgol Mar Res 58:303-310

Franke HD, Gutow L, Janke M (1999) The recent arrival of the oceanic isopod Idotea metallica Bosc off Helgoland (German Bight, North Sea): an indication of a warming trend in the North Sea? Helgol Meeresunters 52:347-357

Gibbs PE, Pascoe PL, Burt GR (1988) Sex change in the female dog-whelk, Nucella lapillus, induced by tributyltin from antifouling paints. J Mar Biol Assoc UK 68:715-731

Hagmeier A (1930) Die Besiedlung des Felsstrandes und der Klippen von Helgoland. I. Der Lebensraum. Wiss Meeresunters (Abt Helgoland) 15:1-35

Harms J (1993) Check list of species (algae, invertebrates and vertebrates) found in the vicinity of the island of Helgoland (North Sea, German Bight) - a review of recent records. Helgol Meeresunters 47:1-34

Harms J, Anger K (1983) Seasonal, annual, and spatial variation in the development of hard bottom communities. Helgol Meeresunters 36:137-150

Hartnoll RG, Hawkins SJ (1980) Monitoring rocky-shore communities: a critical look at spatial and temporal variation. Helgol Meeresunters 33:484-494

Hawkins SJ, Hartnoll RG (1983) Changes in a rocky shore community: an evaluation of monitoring. Mar Environ Res 9:131181

Hawkins SJ, Hartnoll RG (1985) Factors determining the upper limits of intertidal canopy-forming algae. Mar Ecol Prog Ser 20:265-271

Hayward PJ (1985) Ctenostome bryozoans. In: Kermack DM, Barnes RSK (eds) Synopses of the British fauna (new series). Brill EJ and Backhuys W, London Leiden Köln København

Hiscock K, Southward A, Tittley I, Hawkins S (2004) Effects of changing temperature on benthic marine life in Britain and Ireland. Aquat Conserv Mar Freshw Ecosyst 14:333-362
Janke K (1986) Die Makrofauna und ihre Verteilung im NordostFelswatt von Helgoland. Helgol Meeresunters 40:1-55

Janke K (1990) Biological interactions and their role in community structure in the rocky intertidal of Helgoland (German Bight, North Sea). Helgol Meeresunters 44:219-263

Jenkins SR, Hawkins SJ, Norton TA (1999) Interaction between a fucoid canopy and limpet grazing in structuring a low shore intertidal community. J Exp Mar Biol Ecol 233:41-63

Jenkins SR, Aeberg P, Cervin G, Coleman RA, Delany J, Della Santina P, Hawkins SJ, LaCroix E, Myers AA, Lindegarth M, Power AM, Roberts MF, Hartnoll RG (2000) Spatial and temporal variation in settlement and recruitment of the intertidal barnacle Semibalanus balanoides (L.) (Crustacea: Cirripedia) over a European scale. J Exp Mar Biol Ecol 243:209-225

Jenkins SR, Aberg P, Cervin G, Coleman RA, Delany J, Hawkins SJ, Hyder K, Myers AA, Paula J, Power AM, Range P, Hartnoll RG (2001) Population dynamics of the intertidal barnacle Semibalanus balanoides at three European locations: spatial scales of variability. Mar Ecol Prog Ser 217:207-217

Kalbfus W (1997) Butylzinnverbindungen in Nord- und Ostssee. Dt Hydr Z 7:75

Kornmann P, Sahling PH (1994) Marine algae of Helgoland: second supplement. Helgol Meeresunters 48:365-406

Leonard GH, Ewanchuk PJ, Bertness MD (1999) How recruitment, intraspecific interactions, and predation control species borders in a tidal estuary. Oecologia 118:492-502

Lewis JR (1976) Long-term ecological surveillance: practical realities in the rocky littoral. Oceanogr Mar Biol Annu Rev 14:371-390

Lewis, JR (1978) The ecology of rocky shores. Hodder and Stoughton, London

Lubchenco J (1983) Littorina and Fucus: effects of herbivores, substratum heterogeneity, and plant escapes during succession. Ecology 64:1116-1123

Lubchenco J, Menge BA (1978) Community development and persistance in a low rocky intertidal zone. Ecol Monogr 48:67-94

Menconi M, Benedetti-Cecchi L, Cinelli F (1999) Spatial and temporal variability in the distribution of algae and invertebrates on rocky shores in the Northwest Mediterranean. J Exp Mar Biol Ecol 233:1-23

Menge BA (1976) Organization of the new England rocky intertidal community: role of predation, competition, and environmental heterogeneity. Ecol Monogr 46:355-393

Menge BA (1991) Relative importance of recruitment and other causes of variation in rocky intertidal community structure. J Exp Mar Biol Ecol 146:69-100

Menge BA, Sutherland JP (1976) Species diversity gradients: synthesis of the roles of predation, competition, and temporal heterogeneity. Am Nat 110:351-369

Menge BA, Sutherland JP (1987) Community regulation: variation in disturbance, competition, and predation in relation to environmental stress and recruitment. Am Nat 130:730-757

Meyer KB (1971) Distribution and zoogeography of fourteen species of nudibranchs of Northern New England and Nova Scotia. Veliger 14:137-152

Moyse J, Nelson-Smith A (1964) Effects of the severe cold of 1962 63 upon shore animals in South Wales. In: Crisp DJ (ed) The effects of the severe winter of 1962-63 on marine life in Britain. J Anim Ecol 33:183-190

Paine RT (1974) Intertidal community structure. Experimental studies on the relationship between a dominant competitor and its principal predator. Oecologia 15:93-120

Reise K (1998) Pacific oysters invade mussel beds in the European Wadden Sea. Senckenb Marit 28:167-175

Sagarin RD, Barry JP, Gilman SE, Baxter CH (1999) Climaterelated change in an intertidal community over short and long time scales. Ecol Monogr 69:465-490

Southward AJ (1958) The zonation of plants and animals on rocky sea shores. Biol Rev 33:137-177

Southward AJ (1995) The importance of long time-series in understanding the variability of natural systems. Helgol Meeresunters 49:329-333 
Southward AJ, Hawkins SJ, Burrows MT (1995) Seventy years' observations of changes in distribution and abundance of zooplankton and intertidal organisms in the western English Channel in relation to rising sea temperature. $\mathbf{J}$ Therm Biol 20:127-155

Stæhr PA, Pedersen MF, Thomsen MS, Wernberg T, KrauseJensen D (2000) Invasion of Sargassum muticum in Limfjorden (Denmark) and its possible impact on the indigenous macroalgal community. Mar Ecol Prog Ser 207:79-88

Stephenson TA, Stephenson A (1949) The universal features of zonation between tidemarks on rocky coasts. J Ecol 37:289-305

Stephenson TA, Stephenson A (1972) Life between tidemarks on rocky shores. Freeman, San Francisco, CA

Thompson TE (1988) Molluscs: benthic opisthobranchs. In: Kermack DM, Barnes RSK (eds) Synopses of the British fauna (new series). Brill EJ and Backhuys W, Leiden New York København Köln

Underwood AJ (1985) Physical factors and biological interactions: the necessity and nature of ecological experiments. In: Moore PG, Seed R (eds) The ecology of rocky coasts. Hodder and Stoughton, London, pp 372-390
Van Soest (2001) Porifera. In: Costello MJ, Emblow CS, White R (eds) European register of marine species. A check-list of the marine species in Europe and a bibliography of guides to their identification. Patrimoines naturels 50:85-103

Walther GR, Post E, Convey P, Menzel A, Parmesan C, Beebee TJC, Fromentin JM, Hoegh-Guldberg O, Bairlein F (2002) Ecological responses to recent climate change. Nature 416:389-395

Watermann B (1993) Antifoulingrückstände in Wasser und Sediment. Schrreihe Schutzgem Dtsch Nordseeküste Wilhelmshy 2:47-57

Willmann R (1989) Muscheln und Schnecken der Nord- und Ostsee. Melsungen, Neumann-Neudamm

Wiltshire KH and Manly BFJ (2004) The warming trend at Helgoland roads, North Sea: phytoplankton response. Helgol Mar Res 58:269-273

Wolff WJ, Reise K (2002) Oyster imports as a vector for the introduction of alien species into northern and western European coastal waters. In: Leppakoski E, Gollasch S, Olenin S (eds) Invasive aquatic species of Europe: distribution, impacts and management. Kluwer Academic Publishers, Dordrecht, pp 193-205 